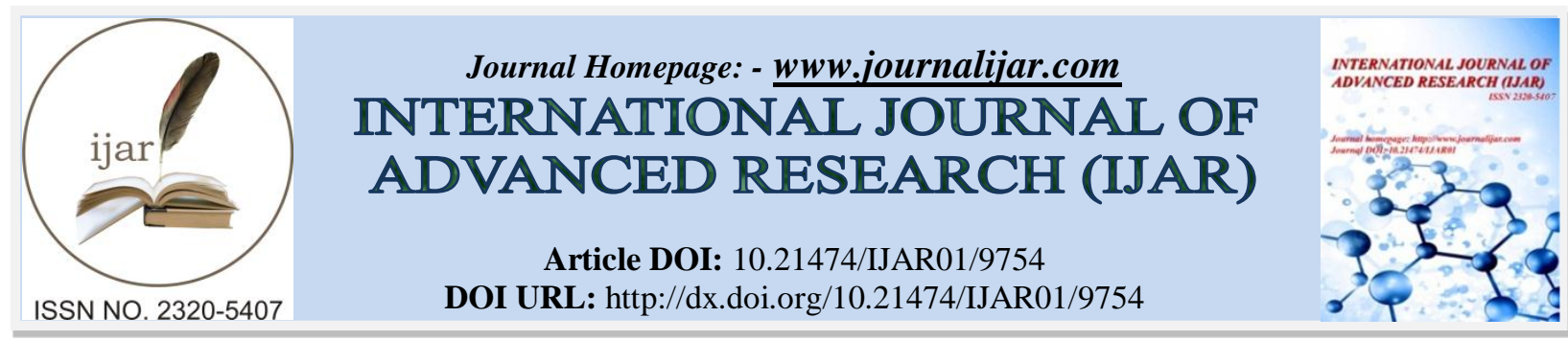

RESEARCH ARTICLE

\title{
ROLE OF RASAYANA DRAVYA AND DIET AS PREVENTIVE MEDICINE IN VYADHI OF MAHASROTASA WITH SPECIAL REFERENCE TO GASTROINTESTINAL TRACT DISORDER: A CONCEPTUAL STUDY.
}

\section{Shinde Ramdas. B. ${ }^{1}$, Jagtap Pooja. A. ${ }^{2}$ and Gulhane J. D. ${ }^{3}$}

1. PG Scholar, Department of Kayachikitsa, Government Ayurved College and Hospital, Nagpur.

2. PG Scholar, Department of Shalyatantra, Government Ayurved College and Hospital, Nagpur.

3. Asso. Prof., Department of Kayachikitsa, Government Ayurved College and Hospital, Nagpur.

\section{Manuscript Info}

Manuscript History

Received: 12 July 2019

Final Accepted: 14 August 2019

Published: September 2019

Key words:-

Rasayana Dravya and diet, Preventive medicine, Mahasrotasa Vyadhi, G.I.T.

\section{Abstract}

The aim of Ayurved is not only for treat the disease but also prevent it. Two types of treatment modalities are explained, one is Svasthasya Urjaskara, in which drugs are given to prevent the disease, another is Artasya Roganut, in which, drugs are given to treat the existing disease in the body. In Ayurveda Rasayana Dravya and Pathya Apathya have key role in preventive measurement. Rasayana Dravya like Amalaki, Rudanti, Haritaki, Bibhitaki, Pippali, Bhallataka, Guduchi etc. are effective on diseases of Mahasrotasa. Mahasrotasa is synonym of Koshta it extends from mouth to the anus. In modern point of view complete Gastro intestinal tract is Mahasrotasa, so the diseases of Gastro intestinal tract are very common in day today life such as acid peptic disorder, diarrhea, constipation, colitis, ascites, irritable bowel syndrome, indigestion etc. and long term use of modern drugs for these diseases cause side effects of Mahasrotasa.

Material and Methods: This is a conceptual study for which various Ayurvedic texts like Brihattrayi, Laghutrayi and various modern medicine books and published research articles and papers and also information available on net will be used.

Result: These problems can be easily prevented by using Ayurvedic preventive measures like Rasayana Dravya and Pathya Apathya without any harmful effects.

Conclusion: The Rasayana Dravya used having properties like Dipana, Pachana, Vatanulomana and Balya, also prevent formation of diseases and help as a probiotic to gut bacteria and keep them healthy. Use of Rasayana Dravya and Pathya Apathya in daily diet can prevent disorders of Mahasrotasa which are hampering day today life activity and also life threatening disorders

Copy Right, IJAR, 2019,. All rights reserved.

\section{Introduction:-}

A primary goal of health care is to prevent disease or detect it early enough so that intervention will be more effective. Tremendous program has been made towards this goal over the last 50 years. Effective preventive

Corresponding Author:-Shinde Ramdas. B.

Address:-PG Scholar, Department of Kayachikitsa, Government Ayurved College and Hospital, Nagpur. 
intervention has resulted in dramatic declines in mortality rate from many diseases. Preventive interventions include counselling about risk behaviour, vaccination, medications and change in lifestyle and diet ${ }^{[1]}$

Mahasrotasa is the term used for Koshta which extends from mouth to the anus. It is also called Abhyantar Roga Marga and Jwara, Atisara, Chardi, Alasaka, Visuchika, Hikka, Anaha, Udara, Arsha are the diseases of Abhyantar Roga Marga or Mahasrotasa ${ }^{[2]}$ In modern science it is correlated with gastrointestinal tract and its diseases like diarrhoea, constipation, piles, ascites, cancers, gastritis, peptic ulcers, malabsorption, colitis, irritable bowel syndrome, anal fissure etc. Disease of gastrointestinal tract are a major cause of morbidity and mortality. Approximately $10 \%$ of general practitioner's consultation are for indigestion and 1 in 14 is for diarrhoea. Infective diarrhoea and malabsorption are responsible for much ill health and many deaths in developing country. The gastrointestinal tract is the most common site for cancer development. Colorectal cancer is the second most common cancer in men. Functional bowel disorders affect up to $10-15 \%$ of the population. ${ }^{[3]}$

In Ayurveda two types of drugs are explained one is Svasthasya Urjaskara, in which drugs are given to prevent the disease which are Rasayana and Vajikarana. Another is Artasya Roganut, in which, drugs are given to treat the existing disease in the body. ${ }^{[4]}$ The word Rasayana is made up of two words one is Rasa and other is Ayana. Rasa indicate the Rasadhi Sapta Dhatus and Ayana indicate the Apyayana means Dhatu Vardhana. It means that Rasayana are those Dravyas who increase the Sapta Dhatu which do not cause any adverse effects on body. Maintain healthy body and long life. ${ }^{[5]}$

In Ayurveda Rasayana Dravya and Pathya Apathya have key role in preventive measurement. Rasayana Dravya like Amalaki, Rudanti, Haritaki, Bibhitaki, Pippali, Bhallataka, Guduchi etc. are effective on prevention of diseases of Mahasrotasa.

Aim:

Literature study on the Role of Rasayana Dravya and Diet as Preventive Medicine in Vyadhi of Mahasrotasa with Special Reference to Gastrointestinal Tract Disorders

\section{Objective:-}

To study the role of Rasayana Dravya and Diet as Preventive Medicine on Mahasrotasa

\section{Materials and method:-}

This is a conceptual study for which various Ayurvedic texts like Brihattrayi, Laghutrayi in addition to which various modern medicine books, published research articles and papers along with information available on internet are used.

Table no. 1:-Showing Properties of Rasayana Dravya

\begin{tabular}{|c|c|c|c|c|c|c|c|c|}
\hline $\bar{S}$ & $\begin{array}{l}\text { Name of } \\
\text { Herb }\end{array}$ & $\begin{array}{l}\text { Latin } \\
\text { Name }\end{array}$ & Rasa & Vipaka & Virya & Guna & Karma & $\begin{array}{l}\text { Chemical } \\
\text { composition }\end{array}$ \\
\hline 1 & Haritaki & $\begin{array}{l}\text { Terminali } \\
\text { a chebulic }\end{array}$ & $\begin{array}{l}\text { Pancharasa } \\
\text { LavanaVarjit } \\
\text { a }\end{array}$ & $\begin{array}{l}\text { Madhu } \\
\mathrm{r}\end{array}$ & Ushna & $\begin{array}{l}\text { Laghu } \\
\text { Ruksha }\end{array}$ & Tridoshghna & $\begin{array}{l}\text { Tannin, } \\
\text { Chebulagic acid, } \\
\text { Chebulinic } \\
\text { acid,Corilagin }\end{array}$ \\
\hline 2 & Bibhitaki & $\begin{array}{l}\text { Terminali } \\
\text { a bellirica }\end{array}$ & Kashay & $\begin{array}{l}\text { Madhu } \\
\mathrm{r}\end{array}$ & Ushna & $\begin{array}{l}\text { Ruksha } \\
\text { Laghu }\end{array}$ & Tridoshaghna & $\begin{array}{l}\text { Tannin, Galic } \\
\text { acid, Ellagic acid, } \\
\text { Mannitol, } \\
\text { Chebulinic acid }\end{array}$ \\
\hline 3 & Amalaki & $\begin{array}{l}\text { Emblica } \\
\text { officinalis }\end{array}$ & $\begin{array}{l}\text { Lavana } \\
\text { Varjit } \\
\text { Pancharasa }\end{array}$ & $\begin{array}{l}\text { Madhu } \\
\mathrm{r}\end{array}$ & Shita & $\begin{array}{l}\text { Guru } \\
\text { Ruksha } \\
\text { Shita }\end{array}$ & Tridoshhara & $\begin{array}{l}\text { Galic acid, Tannic } \\
\text { acid, Albumin, } \\
\text { cellulose, Vitamin } \\
\text { C, Ellagic acid }\end{array}$ \\
\hline 4 & Guduchi & $\begin{array}{l}\text { Tinospora } \\
\text { Cordifolia }\end{array}$ & $\begin{array}{l}\text { Tikta, } \\
\text { Katu, } \\
\text { Kashay }\end{array}$ & $\begin{array}{l}\text { Madhu } \\
\mathrm{r}\end{array}$ & Ushna & $\begin{array}{l}\text { Lghu, } \\
\text { Ruksha }\end{array}$ & $\begin{array}{l}\text { Vatghna,Pittghn } \\
\text { a, } \\
\text { Kaphghna }\end{array}$ & Berberine, giloin \\
\hline
\end{tabular}




\begin{tabular}{|l|l|l|l|l|l|l|l|l|}
\hline 5 & & & & & Mrudu & & \\
\hline Pimpali & $\begin{array}{l}\text { Piper } \\
\text { longum }\end{array}$ & Katu & $\begin{array}{l}\text { Madhu } \\
\mathrm{r}\end{array}$ & $\begin{array}{l}\text { Anushn } \\
\text { a }\end{array}$ & $\begin{array}{l}\text { Laghu } \\
\text { Snighd } \\
\text { h } \\
\text { Tikshn } \\
\text { a }\end{array}$ & $\begin{array}{l}\text { Kaphghna } \\
\text { Vatghna }\end{array}$ & $\begin{array}{l}\text { Piperine, } \\
\text { Piplartine, } \\
\text { Sesamin,Piplaster } \\
\text { ol }\end{array}$ \\
\hline 6 & $\begin{array}{l}\text { Bhallatak } \\
\text { a }\end{array}$ & $\begin{array}{l}\text { Semicarpu } \\
\text { s } \\
\text { anacardiu } \\
\text { m }\end{array}$ & $\begin{array}{l}\text { Katu, } \\
\text { Kashay, } \\
\text { Tikta }\end{array}$ & $\begin{array}{l}\text { Madhu } \\
\mathrm{r}\end{array}$ & Ushna & $\begin{array}{l}\text { Laghu } \\
\text { Snighd } \\
\text { h } \\
\text { Tikshn } \\
\text { a }\end{array}$ & $\begin{array}{l}\text { Kapha Vata } \\
\text { shamak }\end{array}$ & $\begin{array}{l}\text { Bhilawanol, } \\
\text { Semicarpol }\end{array}$ \\
& & & & & \\
\hline
\end{tabular}

Mode of action of Rasayana Dravya modern and Ayurvedic point of view as a preventive medicine Haritaki:

Haritaki contain all five Rasa except Lavana Rasa. It acts as Anulomaka, Dipani, Pachani, Laghu, Sarvaroga Prashamani. It can prevent Gulma, Udavarta, Arsha, Grahanidosha, Atisar, Arochaka, Anaha, Udararoga, Krimi Roga. ${ }^{[6]}$ The main constituent of it is tannins. These are mainly used in medicine primarily because of their astringent properties. Tannin react with the tissue proteins with which they come in contact. In gastric ulcers this tannin protein complex layer protects the stomach by promoting greater resistance to chemical and mechanical injury or irritation. In several experimental model of gastric ulcer, tannin have been shown to present antioxidant activity promote tissue repair, exhibit anti helicobacter pylori effect and they are involved in gastrointestinal tract anti-inflammatory processes ${ }^{[7]}$

\section{Amalaki:}

All properties of Amalaki and Haritaki are same except Virya, Amalaki is Shita Virya and Haritaki has Ushna Virya. It prevents Arochaka, Agnimandya. ${ }^{[8]}$ It contain vitamin $\mathrm{C}$ in large quantity. Vitamin $\mathrm{C}$ is essential for absorption of iron so it can be preventing iron deficiency anaemia, scurvy etc. Vitamin $\mathrm{C}$ also has wound healing property so it can prevent mouth ulcers, peptic ulcers haemorrhoidal bleeding.

\section{Bibhitaki:}

Its work on Mahasrotasa to prevent Agnimandya, Adhmana, Chardi, Arsha, Krimi Roga. ${ }^{[9]}$ it contains Tannin, Galic acid, Ellagic acid it prevents Cancer. Bacterial and viral infections ${ }^{[10]}$

\section{Guduchi:}

It can prevent Agnimandya, Amlapitta, Chardi, Pravahika, Grahani, Krimi Roga. [11] Chemical constitution Barberine. Recent studies have shown that berberine have significant biological effect on gastrointestinal tract and may become therapeutic for the treatment of diarrhoea, gastroenteritis ${ }^{[12]}$

\section{Pippali:}

Pippali Rasayana can be prevented Hikka, Arsha, Grahani, Gulma, Galamayan, Vishamajwara ${ }^{[13]}$ piperine has antitumor properties so it can prevent cancerous growth of tumours. Piperlongumine may have anti cancerous properties in 'in vitro' experiment, it kills some types cancer cells over normal cells. ${ }^{[14]}$

\section{Bhallataka:}

Bhallataka act as Dipana, Pachana Bhedana, Krimighna and liver stimulant, so it can prevent Agnimandya, Pachana Vikara, Vibandha, Anaha, Gulma Udara, Grahani, Arsha ${ }^{[15]}$ Bhallataka is the prime drug on Arsha ${ }^{[16]}$

\section{Rasayana Dravya and Agni:}

Grahani is the main place of Agni where digestion of food takes place Agni is responsible for life if it stopes death will be occurring so only Samagni is responsible for digestion of food and maintain health. Vishamagni, Tikshnagni, Mandagni are responsible for disease. ${ }^{[17]}$ Arsha, Grahani, Atisar are responsible for each other and are mainly caused by Mandagni ${ }^{[18]}$ Hence for healthy and long life Agni has key role and Rasayana Dravya have generally Dipana Pachana properties. By maintaining Samagni with the help of Rasayana Dravya disease free and long life can be possible. 


\section{Diet:}

In Ayurveda diet also have importanceAnnam Vrittikaranam means it provide energy for development of body and daily work.

Atimatrashanam Amapradoshahetunam quantity of food is more than appetite then it responsible for Aama formation.

Yathagni Abhyavaharo Agnisandhukshananam Quantity of diet should be as per appetite to maintain Samagni.

Kalabhojanam Arogyakaranam Taking diet at the time for better health.

Gurubhojanam Durvipakakaranam means heavy diet cannot be digest properly.

Anashanam Ayushohraskaranam long term fasting can be reduce life span.

Ajirnadhyashanam Grahanidushananam taking diet before digestion of prior can hamper gastrointestinal functions. Ekarasabhyaso Dourbalyakaranam diet containing less nutrients causes weakness.

Sarvarasabhyaso Balakaranam diet having all type of nutrients is strengthening body ${ }^{[19]}$

\section{Discussion:}

In modern medicine there are use of vaccines, antisera and some artificially manufactured drugs are use as preventive medicine but there are so many limitations of formation and use of these drugs. Vaccines cannot be given in immunocompromised patient, any defect in live attenuated vaccine can cause disease to the vaccinated body. Preventive medicine is currently faced with the problems of population explosion in developing countries where population overgrowth is causing social, economic and environmental problem. Shortage of these medicine also present problem in front of healthcare system. ${ }^{[20]}$ The gastrointestinal tract disorders like diarrhoea, irritable bowel syndrome, acid peptic disorder, anorectal disorders still there is no any preventive vaccine Rasayana Dravya generally Ushna Virya and Madhura Vipaka so they work as Dipana, Pachana, Vatanulomana and Balya so prevent formation of diseases and help as a probiotic to gut bacteria and keep them healthy. Use of Rasayana Dravya and Pathya Ahara in daily diet can prevent disorders of Mahasrotasa which are hampering day today life activity and also life threatening disorders. Problems of modern preventive medicine can be replacing by Rasayana Dravya and diet.

Now a day's consumption of fast food tremendously increased in daily routine like biscuits, toast, bakery products which made from Maida are causes constipation, Deuto constipation Samagni disturb and it causes acid peptic disorders. By avoiding these bad diet habits prevention of constipation and related disease of gastrointestinal tract can be possible.

\section{Conclusion:-}

Mahasrotasa Vyadhi (Gastrointestinal disorders) can be prevented by using Rasayana Dravya and diet modification without any side effects. This may be hope of ray for those who are susceptible for gastrointestinal disorder.

\section{References:-}

1. Dennis L. K., Stephen L. H. et al, Harrison's Principle of Internal Medicine, Volume $1,19^{\text {th }}$ ed. Published by Mc Graw Hill Education New Delhi, 1999, Chapter no 4, page no 26.

2. Sukla V., Tripathi R., ed. Charak Samhita, Vaidyamanorama Hindi commentary, Choukhamba Sanskrit Sansthan, Varanasi, 2013 Sutrasthan 11/48, page no 177.

3. Brain R. Walkar, et al, ed. Davidson's Principles and Practice of Medicine, $22^{\text {st }}$ ed. Publish Churchill Livigstone Elsevier, 2014, Chapter no 22, page no 840.

4. Sukla V., Tripathi R., ed. Charak Samhita, Vaidyamanorama Hindi commentary, Choukhamba Sanskrit Sansthan, Varanasi, 2013 Chikitsasthana 1/1/4,page no 4.

5. Sukla V., Tripathi R., ed. Charak Samhita, Vaidyamanorama Hindi commentary, Choukhamba Sanskrit Sansthan, Varanasi, 2013 Chikitsasthana 1/1/8,page no 5.

6. Sukla V., Tripathi R., ed. Charak Samhita, Vaidyamanorama Hindi commentary, Choukhamba Sanskrit Sansthan, Varanasi, 2013 Chikitsasthana 1/1/29-34,page no 8.

7. [ https://www.ncbi.nlm.nih.gov>pmc accessed on date 17/9/19]

8. Sharma P. V., Drvyaguna Vigyana, Choukhamba Bharti Academy Varanasi, 2015, Chapter no 9/341, page no 759. 
9. Sharma P. V., Drvyaguna Vigyana, Choukhamba Bharti Academy Varanasi, 2015, Chapter no 4/93, page no 241.

10. [ https://www.emedicinehealth.com accessed on dated 17/9/19]

11. Sharma P. V., Drvyaguna Vigyana, Choukhamba Bharti Academy Varanasi, 2015, Chapter no 9/342, page no 761.

12. [ https://www.researchgete.net accessed on dated 17/9/19]

13. Sukla V., Tripathi R., ed. Charak Samhita, Vaidyamanorama Hindi commentary, Choukhamba Sanskrit Sansthan, Varanasi, 2013 Chikitsasthana 1/3/32-35, page no 29.

14. [ https://en.m.wikipedia.org accessed on dated 18/9/19)]

15. Sukla V., Tripathi R., ed. Charak Samhita, Vaidyamanorama Hindi commentary, Choukhamba Sanskrit Sansthan, Varanasi, 2013 Chikitsasthana 1/2/18-20, page no 24.

16. Shastri A., ed. Sushrut Sanhita, Ayurveda-Tattavasandipika Hindi Commentary Choukhamba Sanskrit Sansthan, Varanasi, 2014, Chikitsasthana 6/19, Page no 51

17. Sukla V., Tripathi R., ed. Charak Samhita, Vaidyamanorama Hindi commentary, Choukhamba Sanskrit Sansthan, Varanasi, 2013 Chikitsasthana 15/3-4,56-57, page no 369.

18. Garde G.K.ed., Sarth Vagbhat, Vagbhatkrit Astanghridaya and its all Marathi translation, Choukhamba Surbharti prakashan Varanasi,2018 Chikitsasthana 8/164, page no.270.

19. Sukla V., Tripathi R., ed. Charak Samhita, Vaidyamanorama Hindi commentary, Choukhamba Sanskrit Sansthan, Varanasi, 2013 Sutrasthan 25/40, page no 338.

20. Park K., Parks Text Book of Preventive and Social Medicine, $23^{\text {rd }}$ ed., M/s Banarasidas Bhanot Publishers, Jabalpur, Chapter no 1, Page no 7. 